\title{
METHODOLOGY FOR DESIGNING AN EDUCATIONAL SUBSYSTEM AS A POLL FROM THE HOUSE OF QUALITY IN MACEDONIAN COMPANIES
}

Elizabeta Mitreva

Goce Delcev University, Shtip, Republic of Macedonia

E-mail: elizabeta.mitreva@ugd.edu.mk; elizabeta.mitreva10@gmail.com

\begin{abstract}
The education of the employees in each instance of a company comes along with a purpose to gain competence and experience in order to realize every business process according to the demands of the products/services, the legal obligation as well as the criteria of competitiveness. Furthermore, it is directly conjoined with the very act of foundation setting of the employees' requests with a unique intention - to achieve quality, stressing the vital need to affiliate everyone in their own field.

This analysis presents the research inputs which are being given in order to get a clear picture whether the Macedonian companies are eager to learn and stimulate both the individual and the collective learning in order to improve the results in general.

According to the given results in the research, it is stated that the Macedonian companies do not pay much attention to quality. They are insufficiently concerned with the continuous education, which is evident in the small investments they make in regard to the innovations. Hence, the quality system has been built in a very small number of companies.

The following model presented in this elaborate has been suggested for a more successful designing and implementation of the educational system as a subsystem of the house of quality. This methodology is integral and has a universal notion which is applicable to all types of companies and institutions as well. Without a conducted training about TQM (Total Quality Management) philosophy and a continued education provided firstly for the managers and further on for all of the employees, the TQM strategy could not be implemented in a satisfactory manner. Also, the benefits that come along with the quality system could not be visible as a result.
\end{abstract}

Key words: educational subsystem, leadership, methodology, quality system, TQM strategy.

\section{Introduction}

One of the fundamental issues of the modern management lays within the operative running of the company on one hand and in the advancement of its performances on the other. All of this results with managing activities which influence the adjustment's preventions. The activities which are performed for improvement and innovations are also directed towards creating changes, according Druskat and Wolf (1998).

In order to keep the self-maintenance through constant improvement on the road that leads from the chaos to flawlessness, the organization itself establishes a dynamic relation between (James, 1996):

- management dictation based upon the strong need to realize the purposes of perfection;

- active learning with a manual for undertaking an action and 
PROBLEMS

OF MANAGEMENT

IN THE $21^{\text {st }}$ CENTURY

Volume 3, 2012

82

- improvement and innovation processes set for using the Deming's cycle (P-D-CA).

\section{Education - One of the Polls in the House of Quality}

New management system that is based upon the TQM (Chepujnoska, 2009) strategy demands quite less money and time. It could also have same or greater effects than the huge equipment investments. The solution lays in the updating of the management system through a new strategy and development of the staff, as well as an upgrade of the processes far before the purchase of the new technology, especially the informational one.

As long as the company is not able to conduct additional education and learn, the steps of improvement (such as deployment of the others' knowledge, or learning from own experiences, participation of every employee, etc.) cannot be taken. On the other hand, Macedonian companies which do not express capability to learn and fail to advance in regard to the technological level, style and management, innovations and quality of the product/service, business performance and the employees' proper behavior, need to act onward with a new approach for improvement that would include a combination of the following:

- leaping improvement and breakthrough towards new performances;

- a conduct of the learning process - qualifying for learning (learning how to learn);

- improvement by the learning from own experiences and deployment of the others' knowledge;

- undertaking innovational leaps.

The problem with our mentality is that all of us persistently and irrationally defy the outer mental model instead of analyzing it and conduct it wisely. Thus, when we accept a new mental model without a detailed analysis, we easily and imprudently give up from the traditional one. Our basic problem is the manner in which we join out traditional values together with the civilizational values and the current in vogue western values that rule around the world.

TQM strategy was a great opportunity for the Japanese (Kratsu, 1995) to join their new mental model, transferring the western world values to their traditional mental model which has been based upon the traditional eastern culture. The results that have been accomplished only by those fellow-citizens who live and work abroad show that they have successfully joined both their great talent and individual mental potential with the world's methods and techniques, which also leads us to the fact about our already existing huge and unused potential.

The improvement of the learning process (EFQM, 1999) could be implemented in an organization where the capability to learn from own experiences and deployment of the others' knowledge in the quest of an answer of the relentless internal and external changes is not questionable. Another essential factor that leads to improvement is the continuation of this process. In order to accomplish the improvements easily, it is necessary to organize every phase in the P-D-C-A cycle impeccably.

\section{Methodology of Research}

The research has been conducted in a form of an attempt to face the current condition within 151 Macedonian companies in the domain of designing and implementation of the educational subsystem as one of polls of the "House of quality" (internal standardization, methods and techniques for flawless business, analysis of quality costs, education and motivation), whose pick is represented by the top management and as base come the measurement, evaluation, analyzing and comparison of the good/bad quality (Mitreva, 2010). A special attention has been given to the gathering of the entering data included in the research. As an instrument, there was 
Elizabeta MITREVA. Methodology for Designing an Educational Subsystem as a Poll From the House of Quality in Macedonian Companies

a questionnaire used that was designed to give an accurate analysis in a manner of complete and correct fulfilling.

At the same time, there were some direct contacts made with the top management and the employees in order to depict the authenticity of the questionnaire and to present the realistic condition of the companies.

The data received from the research are processed with adequate mathematical - statistical methods. In this regard, the Pareto analysis was used for frequency as well as for analysis in order to calculate the involvement of certain answers in percentages. The structure of the examined companies (151) - the participants in the research according the economic activity that it belongs to (National qualification of activities - NKD Rev. 2 - "Official Gazette of R. of Macedonia" no. 147, $26^{\text {th }}$ of November 2008) is given in Figure 1.

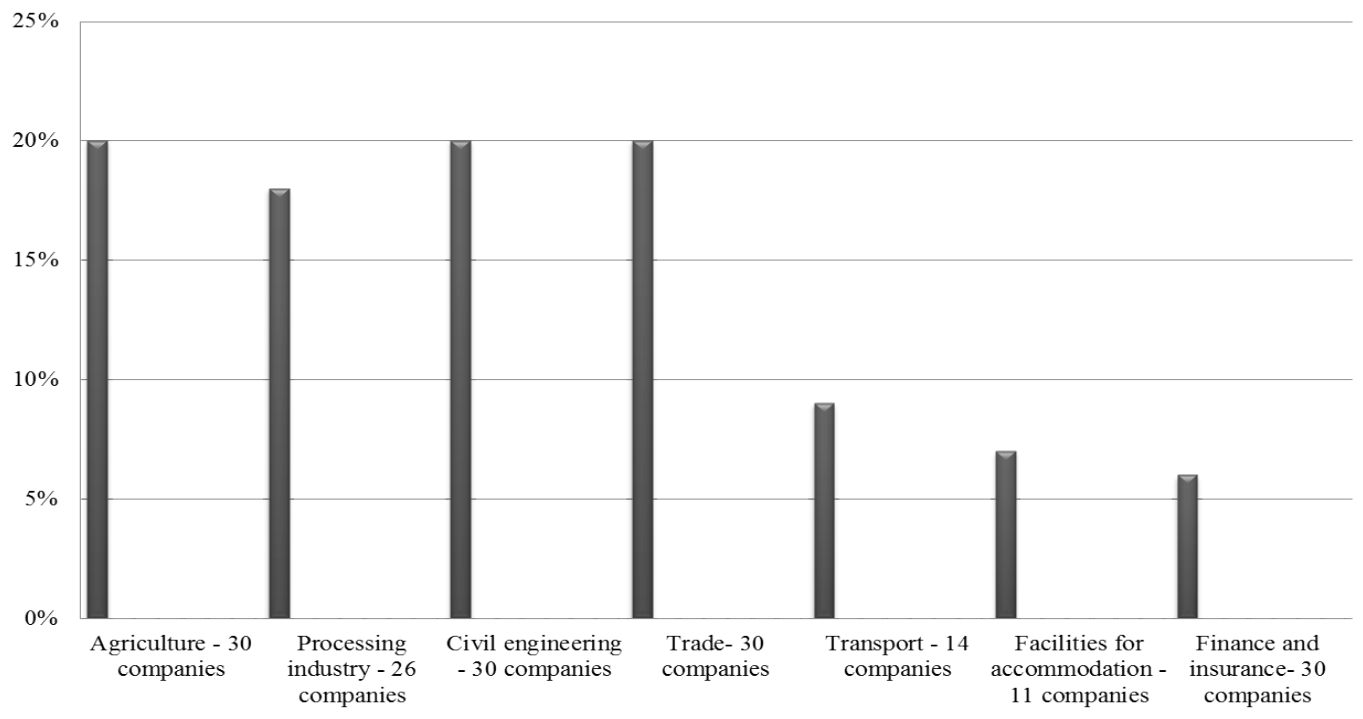

Figure 1: Companies' participation divided according their economic activities.

\section{Results of Research}

\section{Are Macedonian Companies Exposed to Learning?}

The educating process within an organization is a consisting part of the TQM strategy because if new techniques and methods are not being adopted by learning, there is no possibility for advancement and development. The knowledge strengthens the competitive advance of the companies. The most important role of the top management is to meet the demands in order to be prepared to learn and transfer this necessity to the employees.

In order to get a clear picture whether the Macedonian companies are eager to both adopt new knowledge and stimulate the individual and the collective learning subsequently in order to improve the results in general, a few questions have been raised: Do these companies practice to conduct trainings at the workplace or trainings for achieving additional competence?

One hundred forty-seven of the companies have replied on the first part. The following data was gained as a result:

- $64.6 \%$ of the examined have answered that they sometimes practice training at the workplace;

- $\quad 33.3 \%$ of them attended a planned, organized and well-accomplished training;

- $2.4 \%$ of them have never practiced any training.

According to the researches, the most of the trainings have been conducted by the 
PROBLEMS

OF MANAGEMENT

IN THE $21^{\text {st }}$ CENTURY

Volume 3, 2012

companies themselves in order to enable further qualification or prequalification of the employees.

The necessity for the employees to rise a qualification level up is particularly important in concordance with the investment within the modern technology. Our experiences so far indicate the necessity of a continuous training of every employee, especially in regard of the programs which are in accordance with the EU demands.

In order to get a clear picture whether the Macedonian companies conduct regular trainings in order to attain an additional competence of the employees, a question has been raised with a singular aim - to examine the awareness of the top management regarding the need for a continuous professional improvement and development of the employees in the era of knowledge. As for the results, here is the data:

- $56.3 \%$ of the examined have attended a training in order to gain an additional education but only if needed;

- $\quad 26.5 \%$ of them do not practice trainings;

- $13.9 \%$ have attended a training once a year;

- $3.3 \%$ of them have been attending training twice a year which is the annual minimum for a professional promoting.

The fact that $26.5 \%$ of the examined companies do not practice training in order to gain additional competences is quite concerning. Lifelong learning is the ultimatum for survival of the modern businesses.

These realistic indicators point out the fact that the lack of training on regular basis in order to gain additional competence is one of the main reasons for being not competitive with our products on the global market.

Considering the fact that if the existing competence is not being updated, they would become outdated in less than 5 years. The question whether the employees would be competent (in about 40 organizations) if they do not practice further education which is needed in order to fulfill the needs of the modern management work performance.

The analyses of the regular trainings for additional competence within the economical branches, gave the following outcome:

- the sectors such as finance and trading where the trainings have been conducted twice a year, came out with better conditions. Here, the changes in the legal regulative and the market are imposing a necessity of continuous improvement and development of the employees' competence;

- in regard to the improvement of knowledge, the civil engineering has been found in the worst condition, followed by the processing industry, agriculture, and transport and supplying.

If we divide the examined economical subject into two groups (private or public sector), these would be the results:

- the public sector would have $4 \%$ of the examined companies - six where $100 \%$ of the capital is in a public ownership and

- $\quad 96 \%$ would be from the public sector.

The examinations done in the public sector regarding the need of gaining additional competence have shown that (83.3\%) of the examined public enterprises do not practice trainings. They still have a monopolistic position on the market, where a certain excuse for the minor significance of the necessity for innovation and constant improvement of the employees still exists. Nonetheless, the awareness for the significance of the innovations and the constant improvement of the competences with the managers is non-existent. 
Elizabeta MITREVA. Methodology for Designing an Educational Subsystem as a Poll From the House of Quality in Macedonian Companies

\section{Discussion}

Macedonian companies still haven 't comprehended the necessity of knowledge promoting as a source of competitiveness, condition for survival at the market and an initial power triggering further development.

Macedonian companies that are not qualified to perform further education and which are falling behind in regard of the technological level, management style, innovation and product quality/service and business culture of the employees need to take seriously into consideration the implementation and the education in order to develop further the improvement of the quality.

The incompetent education of the top management is one of the issues that Macedonian companies are facing nowadays. Today, there are top managers that have been educated according to the previous system and they cannot accept the changes that inevitably are happening in the present. The companies are visionless about the future and can hardly adapt to the needs of the buyers/consumers. If the managers get a vision where the global economy is moving, as well as what exactly is the thing that the buyers are looking for from the product, it is certain that the solution lays into the survival of Macedonian companies.

The training of the top management prepared in a world example (Mumford, 1996; Harung, 1996) as well as gaining of additional competence for a proactive achievement could seriously influence the successfulness of Macedonian companies. As of the analysis of the Macedonian companies regarding their efficient cooperation with the scientific-researchers, university and other type of educational institutions within the recent years, the following outcomes appear:

These analyses resulted in a weak cooperation and linkage between the companies and the scientific institutions as a result which indicates the fact that those companies are insufficiently informed regarding the possibilities that are being offered by these institutions, or indifference for a scientific approach or work performance.

All of the vide supra is a consequence of an insufficient instruction of the services that are offered by this organizations and programs.

The fact that this analyses regarding the issues of presence of the management in the hierarchy of the organization appears as 3.5\% indicates that a small number of enterprises perform with a single manager - owner and the rest of the staff are merely employees without managing powers, is indisputable. Due to this, the managers are either dealing with shortage of time or they develop a single interest regarding a cooperation that would lead them to instant results.

Countries that are into a process of a slow transition such as ours, the domestic brainpower, knowledge, learning investments, experience, competencies and especially the technical and technological occupations are reaching quite a low level. The responds to all this adjustments within these types of companionship are expected abroad, from the foreign investments.

According to the given results in the research (Mitreva, 2010), it is stated that Macedonian companies do not care about the quality. They insufficiently pay attention to the continuous education, make small investments in the innovations and over all - the quality system is built in a very small number of companies. This analyses displays the following model for a successful designing and implementing of the educational system as a subsystem of the house of quality is suggested (Mitreva, 2010). This model should be universal and applicable to all companies, figure.2. 
PROBLEMS

OF MANAGEMENT

IN THE $21^{\text {st }}$ CENTURY

Volume 3, 2012

INTEGRAL METHODOLOGY FOR DESIGNING AND IMPLEMENTING

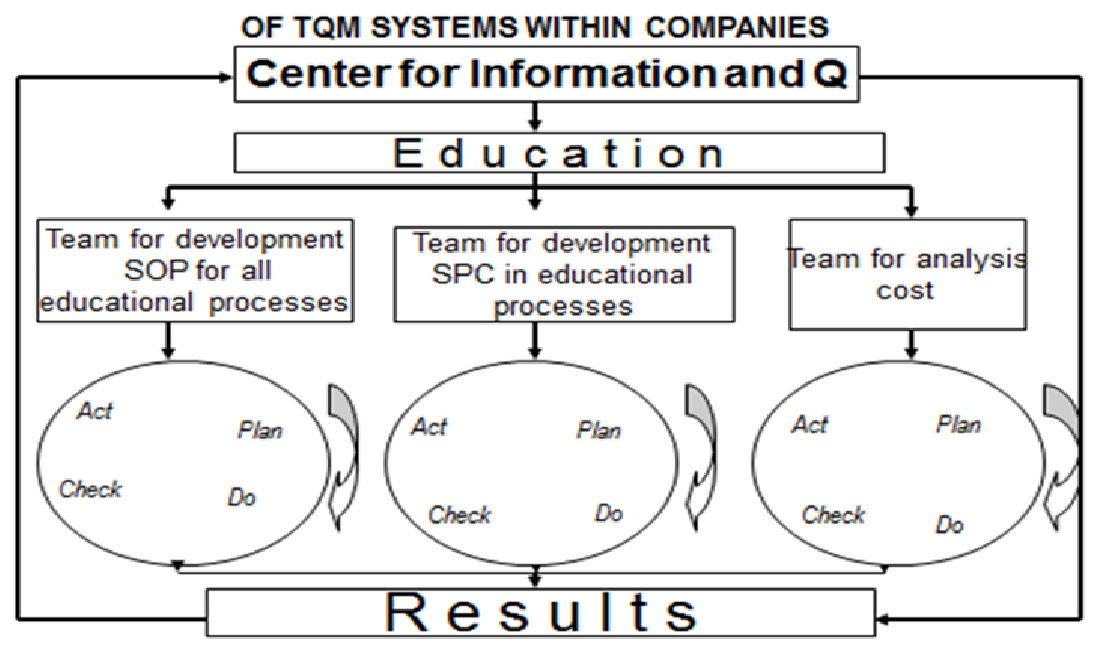

Figure 2: Methodology for designing an educational subsystem as a poll from the house of quality.

Application of the integral methodology for designing and implementing of the TQM system has to start with the education and therefore a good educational subsystem in the learning institutions should be prepared. It should be done in a way in which it would be easy to adopt the knowledge as well as to adjust to the changes. Furthermore, the knowledge should be used for a personal development and designing as well.

Complex knowledge of the system according to TQM should be expanded from the top person of the company-general manager and up to each employee with a different volume and substantiality for different functions of the company's work.

The educational process planning is a task for the top management that bears the responsibility to establish a department for education. This service should prepare plans and programs of different levels in order to provide quality, concordance with the functions and tasks done by the companies, using the methodology and applications of the Deming's Quality Circle.

The staff education within the whole institutional structure is intended for the employees to gain skills and experience so they could accomplish business processes in accordance with the products' demands, services, legal obligations and criteria for suitability and appointment of the employees, because the quality demands involvement of everyone to its own job responsibility.

\section{Organization and Function of the Service for Educational Quality}

This service within its organization and working methodology needs to fulfill the following obligations:

- identification of the educational needs of the employees according to their position, task content and the organ of the quality management functions;

- cooperation with experts and scientists;

- building and alleging of the educational programme;

- alleging, checking and realization of the educational concept;

- designing and application of the motivational activities within the quality educational system within the company; 
- constant improvement of the skills-development system of the employees as a

precondition of the quality system.

The education service is preparing different programs aimed for different quality management levels, differentiated according the basic levels of the organizational structure. The education according the organizational structure refers to:

1. management of the strategy;

2. tactical and/or operative management;

3. the employees.

The training according to the organizational structure includes realization of the following steps:

\section{Step 1: Education of the strategy management}

Education of the strategy management is being performed by the school for quality and the creative quality workshops, where the staff will attain:

- fundamental introduction of the philosophy top management, elements, roles, meaning, functioning and assets of the total quality management system;

- interpretation of the quality circle and the TQM philosophy, introduction of the quality circle in certain function within the institution;

- education about the quality methods and techniques in all institution functions;

- education about optimization of business processes. improvement

Forms of management education of such level are the schools and workshops for quality training. The programme refers to a detailed elaboration of problems and quality control management. Besides the introduction with the TQM philosophy, methodology and experience, the managers ought to acquire knowledge for:

- quality circle and its application to all institutional functions;

- quality control management within the whole company;

- implication, promotion and education quality control;

- more detailed analyzing and development of the relation between the quality control and the confidentiality;

- application of the statistical methods and control techniques.

Step 3: Education of the employees from certain sectors (services/departments).

The content of this programme is designed to provide skills on: the gist and the TQM philosophy, methodology of the quality system, and especially attaining operational skills for comprehension of the quality system. As through the quality workshops the employees would get the following training:

- training for realization of the business processes;

- training for application of the quality methods and techniques;

- training at the work place - insisting on the training until the employee gets the results within the frame of the statistical process control;

- training defined with legal regulations;

- in case of introduction of new product/service, technology or methods of working, the full training programme is necessary for all of the employees;

- gaining additional skills in order to make the people feel safe for their work positions in future, as well as gaining new skills that would be useful to maintain their current positions;

- stimulation of everyone for additional training as well as being a good example to the others.

Besides that, the employees need to be skilled and motivated to learn from others in order to allow improvement of the personal skills and competences. 
PROBLEMS

OF MANAGEMENT

IN THE $21^{\text {st }}$ CENTURY

Volume 3, 2012

Duration of the Educational Process

The duration of the educational process has to be performed by Deming's circle of quality and could be described with a block diagram.

Company management has an obligation to provide all the conditions for successful realization of the education programs which by themselves require a detailed analysis and provision of the most suitable answers for: what, who, whom, when, where and how in the company's hierarchy needs in order to attain the necessary competence for providing quality. Within the planning phase of the education process, the following steps need to be conducted:

(Plan) Step 1: Plan for staff education

- education service needs to prepare a plan for staff training.

Step 2: Selection of teachers (experts, specialists) within the company or externals in order to realize the training

The external education could be realized under mentorship of external experts within the field of the TQM philosophy trough specialized programs, seminars and trainings which would aid the transfer of the experience coming from the developed countries.

Internal education is conducted through workshops consisted of 5-15 employees, under the mentorship of an expert who is competent as well as well-informed upon the issues and the causes of problems, weaknesses, mistakes etc.

Step 3: Selection of participants in the training employed in different company sectors

The selection of participants is done according to a special questionnaire and testing. The defining of the questions, analysis of the results and the selection itself should be done by competent professionals and institutions.

(Do) Step 4: Realization of the education

The realization of the training has to be conducted within the company's premises, with well-adjusted working conditions, by assisted teaching and surveillance tools.

The quality of knowledge and education transfer of the participants will be dependent on the trainers' skills and capabilities, the participants' interests, availability of written materials, surveillance means etc, but mostly from the interaction between the trainers and the participants.

Significant factors for quality providing within the educational process are: working conditions, motivation, and permanence in the work performance and responsibility.

(Check) Step 5: Competence checkup

The competence checkup is a consistent element of the education process quality as well as part of the participants training and their active participation. This is done by:

- questions, tests, discussions - as the first part of the checkup, but same as

- assigning tasks - as a second part of the educational process.

Through the competence checkup we test:

- the trainers' successfulness;

- application of the educational programmes;

- participants' capacity.

Those results are used not only for the final evaluation of the seminar's efficiency, but also for undertaking adjustment measurements for further improvement of the educational process quality of the company.

(Act) Step 6: adjustment of the programme

The adjustment is very important of the education process. It is realized according the evaluation of the successfulness of the previous seminar. The adjustments could refer to:

- selection of trainers; 
Elizabeta MITREVA. Methodology for Designing an Educational Subsystem as a Poll From the House of Quality in Macedonian Companies

- programme content;

- motivation activities for attending of the training;

- conditions for program performing etc.

\section{Conclusions}

According to the given results in the research, it is notable that the Macedonian companies insufficiently pay attention to the continuous education. They make small investments in the innovations and over all. Also, the quality system is built in within a very small number of companies.

In this paper the following model for a successful designing and implementation of the educational system as a subsystem of the house of quality is suggested. This model should be universal and applicable to all companies. The implementation of this methodology in our companies in not an easy task and could become a barrier that needs to be overcome without expectations that someone else will do it instead. Besides that, the employees need to be capable and motivated to learn from others in order to achieve improvement of the personals skills and competences.

\section{References}

Bowen, D. (1993). One piece at a time, European Quality, Showcase Edition, pp. 55-58.

Bahtijarevic-Siber, F. (1999). Human Resource Management. Golden marketing, Zagreb, pp. 557.

Conti, T. (2002). Quality models and their role in organizational improvement. The Best on Quality. International Academy for Quality, Vol. 12, Quality Press, Milwaukee, WI.

Chepujnoska, V. (2009). Quality Management - Theory, Science and Practice. Faculty of Metallurgy, Skopje, pp. 5-137.

Dijkstra, L. (1997). An empirical interpretation of the EFQM framework. European Journal of Work and Organizational Psychology, 6 (3), 321-41.

Dahlgaard, J. J., Dahlgaard-Park, S. M. (2004). 4P strategy for breakthrough and sustainable development, European Quality, 10 (4), 6-20.

Druskat, V. U., Wolff, S. B. (2001). Building the Emotional Intelligence of Groups. Harvard Business Review, March, 81-90.

Dessler, G. (2003). Human Resource Management. Ninth Edition, Pearson Education, New Yersey, pp. 318.

Drew, S. A. W., Smith, P. (1995). The Learning Organization: Change Proofing and Strategy. The Learning Organization, 2 (1), 7.

James, P. (1996). Total Quality Management: An Introductory Text. Prentice-Hall, Englewood Cliffs, NJ, pp.106-220.

Harung, H. S. (1996). A world-leading learning organization: a case study of Tomra Systems, Oslo, Norway. The Learning Organization: an International Journal, 3 (4), 22-34.

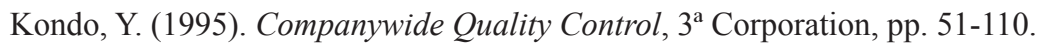

Kratsu, H. (1995). Tokai University, “Concept engineering points in developing hit products”, JUSE, Societas Qualitatis, 9 (2), 3.

Mitreva, E. (2010). Integral Methodology for Designing and Implementing of TQM System within Companies. Skopje, pp.100-159.

Mertins, K., Hersing, P., Vorbeck, J. (2004). Knowledge Management. Springer, Berlin pp. 5. 
OF MANAGEMENT

IN THE $21^{\text {st }}$ CENTURY

Volume 3, 2012

Nabitz, U. W., Klazinga, N. S. (1999). EFQM approach and the Dutch quality award. International Health Care Quality Assurance, 12 (2), 65-70.

Oakland, J. S., Porter, L. (1994). Cases in Total Quality Management. Butterworth Heinemann, Oxford, pp. 181.

Advised by Dana Egerova, University of West Bohemia, Czech Republic

Received: January 11, 2012

Accepted: February 15, 2012
Elizabeta Mitreva

Ph.D., Associate Professor, Faculty of Tourism and Business Logistics, Gevgelija, Goce Delcev University, Shtip, Marsal Tito, 58/1/6, Skopje, Republic of Macedonia.

E-mail: elizabeta.mitreva@ugd.edu.mk, elizabeta.mitreva10@gmail.com Website: http://www.ugd.edu.mk/ 